Juan

Ignacio

Contardo

González

Universidad Diego

Portales, Chile

juan.contardo@mail.udp.cl

Recibido: 10.08 .17

Aceptado: 8.09.17

\title{
La indemnización de perjuicios en caso de resolución frente a la existencia de pluralidad de deudores
}

\section{Compensation against the existence of multiple debtors in termination for breach of contract}

Resumen: El artículo indaga la forma de distribución de la indemnización de perjuicios en caso de resolución por incumplimiento frente a la pluralidad de deudores. Se postula que debe distinguirse entre codeudores mancomunados, solidarios e indivisibles.

Palabras clave: Responsabilidad contractual, indemnización, resolución por incumplimiento, pluralidad de deudores.

El artículo 1489 del Código Civil, que genera para el acreedor la opción entre la pretensión de cumplimiento y la resolución más indemnización de perjuicios por el incumplimiento de un contrato bilateral, se coloca en la hipótesis de un deudor y un acreedor en la relación obligatoria.

Sin embargo, cuando la obligación es de sujeto plural, esto es, mancomunada, solidaria o indivisible, se presenta el problema de determinar cómo opera la resolución entre estos
Abstract: The article investigates the compensation for damages in the event of termination for breach against multiple debtors. We hypothesize that it must distinguish between joint, integral and indivisible debtors.

Keywords: Termination for breach, damages for breach, multiple debtors. varios sujetos y cómo se distribuye la responsabilidad entre esta pluralidad de sujetos. Por distribución de la responsabilidad entendemos la forma en cómo han de responder los deudores de la relación, si de manera mancomunada, solidaria o indivisible.

La doctrina nacional ha analizado el problema solo desde el punto de vista de la pluralidad de sujetos y la resolución, no de la indemnización que sigue a la resolución que es el objeto del siguiente trabajo'.

\footnotetext{
${ }^{1}$ En adelante, a la indemnización en caso de resolución se le denominará indistintamente "indemnización resolutoria" o "perjuicio resolutorio".
} 
En lo primero, es decir, en lo relativo al ejercicio de la resolución frente a la pluralidad de deudores, la doctrina se encuentra dividida. Para algunos, la pluralidad de sujetos implica una suerte de "indivisibilidad" de la relación. De esta manera todos los deudores deben ser demandados de resolución, y todos los acreedores deben demandar de resolución. Por el contrario, para otros, la resolución puede demandarse separadamente a cada deudor, y por tanto habría una "divisibilidad" resolutoria.

Esta discusión plantea necesariamente consecuencias en lo tocante a la indemnización de los perjuicios en caso de resolución. Es decir, de qué manera responderán el o los deudores de la obligación.

Esta disparidad de criterios (la "divisibilidad" e "indivisibilidad" resolutoria), y las implicaciones que tendría en la indemnización resolutoria, creemos que se ha dado porque la resolución (o lo que entendemos hoy como tal) y las distintas formas de pluralidad pasiva, nacen en momentos históricos distintos. En efecto, la creación de las categorías de sujeto plural proviene fundamentalmente del derecho romano basado en la estipulación romana (Guzmán 2013, t. II, pp. 79 y ss.) Por el contrario, la resolución por incumplimiento nace en la modernidad principalmente a partir del desarrollo por Pothier de las ideas que había postulado con anterioridad Domat $^{2}$. Es decir, la creación de lo que nosotros entendemos como resolución por incumplimiento nace no teniendo especialmente en vista la posibilidad de pluralidad de sujetos y es muy posterior a las antiguas clasificaciones de las obligaciones de sujeto plural. Prueba de ello son los ejemplos que da Pothier al tratar la materia (1839, §672, p. 434); e incluso nuestro Código Civil, que precisamente se coloca en el caso de un deudor y un acreedor en el artículo 1489 (y sus correspondientes artículos 1823, 1873 y 1925). Pero, la Ley no da luces de lo que sucedería frente a la pluralidad subjetiva.

Sin embargo, la generalización de las categorías de contratos bilaterales y de obligaciones de sujeto plural en los Códigos hace perfectamente posible concebir contratos de esta naturaleza que contengan multiplicidad de acreedores y/o de deudores. De aquí que el problema de los sujetos frente a la resolución, aunque no es común, ha sido planteado por alguna doctrina tanto nacional como extranjera.

Por tanto, a la hora de analizar el desenvolvimiento de la resolución y la indemnización de perjuicios, se presenta el problema de la distribución del perjuicio resolutorio. Es decir, cómo debe repartirse la indemnización entre los varios deudores condenados cuando sea procedente la resolución. Por las razones enunciadas, el problema de la distribución del perjuicio resolutorio parte de una base concreta: cómo se comporta la resolución cuando hay pluralidad de deudores. De este modo, las opciones que se adopten frente a este tema influyen sustancialmente en la manera cómo se distribuye el perjuicio resolutorio. Así, no parece posible atacar el problema de la distribución del perjuicio resolutorio, sin resolver primero cómo se desenvuelve la resolución frente a la pluralidad de deudores, distinguiendo las diversas clases de deudores, según sea el caso.

De esta manera, para los efectos de esta investigación, se postula que el problema de la distribución tendría especial importancia en la mancomunidad y la solidaridad pasiva, ya que en la indivisibilidad, por expresa disposición de la Ley, el problema de los perjuicios ha sido reenviado al tratamiento de las obligaciones simplemente conjuntas. En los demás casos, a pesar de que no existen reglas particulares, hay razones de texto que permiten solucionar la cuestión planteada. Proponemos entonces un acercamiento desde el punto de vista de las normas del Código para determinar cuál es la situación de la pluralidad de sujetos frente a la indemnización de los perjuicios resolutorios (2.) Esta aproximación se diferencia de las posturas que clásicamente han sido sostenidas por la doctrina que se fundan solo en los efectos extintivos de la resolución sin atender del todo a la naturaleza propia de las distintas clases de pluralidad de deudores (1.)

Debemos hacer presente que el problema expuesto es poco frecuente en la práctica. De hecho, lo común es que la relación jurídica obligatoria se presente entre un acreedor y un deudor. Prueba de ello es que el tópico

${ }^{2}$ Sobre el particular, debe consultarse a Dell'Aquila (1981), p. 31 y ss., especialmente pp. 63-89. 
es tratado de manera muy excepcional por la doctrina nacional y extranjera y hay muy pocos fallos sobre la materia. $Y$ cuando la doctrina le presta atención a ello, tanto en el medio nacional como extranjero, se limita al estudio de la pluralidad de deudores solo frente a la resolución, no de la indemnización consecuencial a ella, tema al que se reduce la investigación. Con todo, creemos que se justifica el análisis del supuesto propuesto (resolución e indemnización frente a la pluralidad de deudores) desde varias ópticas. En primer lugar, porque permite un replanteamiento de los efectos de la resolución desde el plano de sus consecuencias frente a la pluralidad de deudores, en especial, frente a la indemnización. En segundo lugar, permite dimensionar la función de la resolución, como medio de tutela del acreedor, en relación con el incumplimiento y su coordinación con la indemnización de perjuicios. Y, en tercer lugar, a pesar de lo excepcional del tema, permite un cuestionamiento de la función resarcitoria de los perjuicios cuando hay pluralidad de deudores.

\section{El punto de partida: las tesis de la "divisibilidad" e "indivisibilidad" resolutoria}

Tal como se introdujo, para el análisis de la distribución del perjuicio resolutorio es necesario determinar cómo opera la resolución frente a la pluralidad de deudores. En el derecho nacional hay dos principales doctrinas: (1) la tesis que llamamos de la "indivisibilidad" resolutoria, que postula que todos los deudores (mancomunados, solidarios o indivisibles) deben ser demandados de resolución; y (2) la tesis de la "divisibilidad" resolutoria, que afirma que pueden ser solo algunos de los deudores demandados de resolución y los demás no de manera obligatoria. En lo sucesivo, se dará cuenta de los principales postulados de cada una de estas teorías, sus consecuencias en lo tocante a los efectos de la resolución y sus implicancias teóricas en la distribución del perjuicio resolutorio. Hacemos presente que el problema se reduce con especialidad al caso de obligaciones simplemente conjuntas, que es el tipo de obligaciones que parece ser más difícil de solucionar.

\subsection{La tesis de la "indivisibilidad" resolutoria}

Por "indivisibilidad resolutoria" llamamos a la doctrina que estima que la resolución debe ser demandada por todos los acreedores, y en contra de todos los deudores. De esta suerte, la resolución declarada debiera tener efecto respecto de todos los sujetos de la relación obligatoria. Es decir, el remedio de la resolución impediría que se pueda resolver el contrato respecto de unos y no respecto de otros.

\subsubsection{Fundamento}

En la doctrina nacional la indivisibilidad resolutoria ha tenido un doble fundamento.

Para algunos autores la indivisibilidad resolutoria estaría ordenada por ley en el artículo $1526 \mathrm{~N}^{\circ} 6$ a propósito de las obligaciones indivisibles. La norma prescribe que hay excepción a la mancomunidad (activa o pasiva): "Cuando la obligación es alternativa, si la elección es de los acreedores, deben hacerla todos de consuno; y si de los deudores, deben hacerla de consuno todos éstos".

En el entender de los autores partícipes de esta interpretación, el derecho del acreedor de solicitar el cumplimiento o la resolución del contrato según el artículo 1489 del Código Civil se configuraría como una suerte de obligación alternativa, de tal manera que no le sería posible exigir respecto de alguno de los deudores el cumplimiento y respecto de los otros la resolución del contrato (Vío, 1945, p. 361; Alessandri, 2003 t. II, v. 2, $\S 1748$; Peñailillo, 2003, p. 444). Aunque técnicamente en el $N^{\circ} 6$ del artículo 1526 no hay indivisibilidad de pago, sino de opción (Peñailillo, 2003, p. 344), el parecer de esta doctrina es aplicar la solución mutatis mutandis a la opción entregada en el artículo 1489. Esto es, como se trata de una alternativa entre cumplimiento y resolución (más indemnización de perjuicios), en caso de pluralidad de acreedores, deberían todos demandar la resolución; y por el contrario, en caso de pluralidad de deudores, deberían ser todos demandados por lo mismo.

Otro argumento a favor de esta postura ataca a una cuestión de fondo, alejándose del artículo 1526 № 6 : 
la aceptación de una resolución parcial subjetiva (en cuanto a los sujetos) implicaría una reforma al contrato que atentaría contra lo consentido por las partes (Peñailillo, 2003, pp. 444-445).

Entendemos que este fundamento apunta a dos cosas. En primer lugar, atiende al principio de la fuerza obligatoria del contrato. Una resolución parcial subjetiva dejaría entregada la suerte del contrato en manos del acreedor quien tendría la libertad de elegir a quiénes se les exige el cumplimiento y a quiénes se les exige la resolución del contrato, vulnerando el principio de la fuerza obligatoria. El mentado principio ordenaría que el contrato se cumpliese en su totalidad respecto de todos, y no solo respecto de parte de ellos. En segundo lugar, una resolución parcial subjetiva podría afectar las reglas de integridad y de identidad del pago. Si se aceptara la resolución parcial subjetiva podría variarse unilateralmente el objeto de la obligación, que será solo debido en parte respecto de aquellos deudores a quienes se les ha solicitado el cumplimiento.

1.1.2. Implicaciones de la tesis de la indivisibilidad resolutoria en la concepción sobre los alcances de la resolución

Desde este punto de vista, la resolución exigiría un acto de disposición del acreedor del crédito completo (Fernández, 2003, p. 1679) Por tanto, la tesis que sostiene la indivisibilidad resolutoria implica que la resolución del contrato constituye extinción del contrato y no solo la extinción de la relación obligatoria³. Lo que se extinguiría a través de la resolución es todo el contrato, ya que son todos los sujetos de la obligación quienes se encuentran subordinados a la elección soberana del acreedor (o acreedores) del art. $1489^{4}$.

Lo anterior se produciría porque la tesis de la indivisibilidad resolutoria supone que el incumplimiento de cualquiera de los deudores mancomunados puede (siempre que concurran los requisitos de la resolución) ser considerado como incumplimiento resolutorio. Esto es, si el incumplimiento de cualquiera de los deudores mancomunados es considerado como resolutorio, permitiría, precisamente, abrir la posibilidad de que el acreedor pueda demandar la resolución respecto de todos. Por el contrario, si el incumplimiento del deudor mancomunado no fuere considerado como incumplimiento resolutorio, entonces el acreedor gozará de los demás remedios que el ordenamiento jurídico le confiere para la protección de su crédito.

\subsubsection{Consecuencias en la indemnización de los perjuicios resolutorios}

Según la tesis de la indivisibilidad resolutoria, deben ser todos los codeudores mancomunados demandados de resolución, según se ha señalado. Por lo tanto, si concurren los requisitos para que tenga lugar la resolución del contrato, todos los deudores mancomunados deberían ser considerados como sujetos pasivos de la acción por perjuicios resolutorios, entendiendo que la acción por perjuicios resolutorios normalmente ha sido considerada como dependiente de la resolución ${ }^{5}$.

La solución a la que lleva la teoría de la indivisibilidad resolutoria, esto es, que todos los deudores mancomunados son a su vez sujetos pasivos de la acción por perjuicios, abre interrogantes en lo tocante al monto sobre el cual son responsables. Porque si bien la obligación se mantiene de naturaleza divisible, la tesis de la indivisibilidad resolutoria obliga a preguntarse si esta suerte de indivisibilidad resolutoria se mantiene en lo tocante a los demandados por perjuicios, cuestión que no parece encontrar solución entre los autores.

\subsection{La tesis de la "divisibilidad" resolutoria}

Llamamos "divisibilidad" resolutoria a aquella tesis que

\footnotetext{
${ }^{3}$ El problema de los alcances extintivos de la resolución ha ido muy de la mano con la extensión que debería otorgársele a un supuesto efecto retroactivo de la resolución. Se ha sostenido con bastante frecuencia que la resolución operaría con efectos retroactivos, de forma bastante similar a la nulidad del contrato. De esta manera, la resolución borraría todo el contrato. Para un resumen, véase Pizarro (2012, p. 450, notas 5 y 7). Si esta conclusión la extendemos para la situación de la pluralidad de sujetos, la resolución implicaría una extinción de todas las relaciones jurídicas que pudieran nacer con ocasión del contrato.

${ }^{4}$ En este sentido, Cristóbal señala: "Un cierto grado de unidad siempre será observable en la relación obligatoria mancomunada, derivado del origen unitario de la misma, del hecho de que determinados acontecimientos jurídicos, atinentes a uno de los vínculos, son susceptibles de afectar también al todo obligacional (ad exemplum, la resolución contractual ex artículo 1.124 [equivalente a nuestro art. 1489] por incumplimiento de uno de los deudores mancomunados), de las circunstancias de que el negocio generador habrá de contemplarlo en todo momento bajo el prisma de que el mismo ha producido una relación obligatoria con pluralidad de sujetos, lo que influirá a la hora de determinar su alcance y sentido, y, desde luego, de la faceta procesal que en el momento de reclamar el cumplimiento de las particulares obligaciones en que aquélla se descompone tenga lugar la acumulación judicial de acciones" (Cristóbal, 1990, p. 225).

${ }^{5}$ Más que analítica, la doctrina es más bien descriptiva del status quo jurisprudencial: Véase por ejemplo: Peñailillo (2003), p. 434.
} 
sostiene que la relación puede resolverse respecto de algunos de los sujetos pasivos, mas no obligatoriamente respecto de todos.

\subsubsection{Fundamento}

La tesis de la divisibilidad resolutoria se fundamenta en las bases propias de las obligaciones mancomunadas: la obligación es de carácter divisible, por lo que cada deudor lo es de su cuota.

Si cada deudor lo es de su cuota, entonces, el incumplimiento de las obligaciones de cada uno de ellos no perjudica ni arrastra a los demás deudores puesto que las obligaciones que nacen del contrato son del todo independientes.

En el medio nacional, Pescio y Meza son partidarios de esta posición. Al respecto dan tres argumentos: $1^{\circ}$ ) Se admite en la prestación divisibilidad cuotativa; $2^{\circ}$ ) Si la ley permite incluso la nulidad parcial subjetiva (art. 1690), con mayor razón debería permitirse una resolución parcial subjetiva; y $3^{\circ}$ ) Porque la pretensión de cumplimiento no es siempre intrínsecamente indivisible como la de pagar el precio en la compraventa (Pescio, 1961, pp. 88-91; Meza, 2007, pp. 55-56).

\subsubsection{Implicaciones de la tesis de la divisibilidad resolutoria}

La divisibilidad resolutoria implicaría en la práctica que el acreedor solo podrá exigir la resolución respecto de cada deudor mancomunado de la obligación respecto de su propio incumplimiento, independientemente del comportamiento de los demás.

Es consecuencia de lo anterior, también, que el acreedor podría exigirle a algunos de los codeudores el cumplimiento y a otros, la resolución del contrato.

Por lo tanto, la aceptación de una resolución parcial subjetiva hace que necesariamente se acepte una extinción de la relación obligatoria y no una extinción de todo el contrato ${ }^{6}$. Según esta postura debe analizarse cada relación jurídica separadamente, independiente de que haya nacido en un mismo contrato.

Y así, según esta postura, debería el incumplimiento de cada deudor mancomunado ser calificado en su propio mérito como resolutorio o no, y separadamente respecto al cumplimiento o incumplimiento de los demás deudores. Por ejemplo, si en un contrato bilateral un deudor mancomunado se obliga a pagar 60, y los otros dos, a pagar 20 cada uno, e incumple solo el deudor obligado a pagar la mayor cantidad, no podría el acreedor solicitar la resolución del contrato respecto de todos, sino solo del deudor incumplidor aunque monetariamente la obligación sea de mayor entidad que la de los demás codeudores solidarios. Asimismo, si el acreedor demandara la resolución respecto de todos, los deudores de 20 podrían enervar la acción resolutoria a través de la excepción de pago, que solo beneficiará a ellos y no al primer deudor.

\subsubsection{Consecuencias en la indemnización de los} perjuicios resolutorios

Como se acaba de señalar, la tesis de la divisibilidad resolutoria implica que cada deuda mancomunada debe analizarse independientemente.

Esto sugiere que cada deudor, en principio, es obligado y responsable separadamente de los demás. Porque como cada deudor puede ser demandado separadamente de resolución, entonces, habrá que determinar si el incumplimiento de su obligación, de su parte en la deuda, es o no resolutorio. Y solo posteriormente, cabe determinar cuáles son los perjuicios por los cuales responde.

Si se sigue la cadena argumentativa que se viene describiendo, no se trata a través de la tesis de la divisibilidad que los perjuicios se dividan entre todos los deudores mancomunados por el incumplimiento de todo el contrato, sino que el juicio de responsabilidad debería ser considerado tan independiente como el análisis de procedencia de la resolución por incumplimiento.

\footnotetext{
${ }^{6}$ Teniendo en cuenta lo expresado en la nota 3, si se toma una posición más moderada sobre el problema de la retroactividad, tal como lo hace Pizarro (2012) el resultado sería que no todo el contrato se extingue, sino que este entra en una fase de liquidación de las relaciones jurídicas pendientes. Pues bien, en el marco de una relación bilateral con pluralidad de sujetos, habría que conceder que lo que en verdad estaría sujeto a liquidación son las relaciones jurídicas particulares y no todos los sujetos que han intervenido en ella.
} 


\section{La responsabilidad por perjuicios resolutorios en caso de pluralidad pasiva de sujetos}

Después de describir el estado de la cuestión en doctrina nacional, nos abocaremos al estudio de la distribución del perjuicio resolutorio en caso de pluralidad de sujetos. Tal como adelantamos, la manera de entender los efectos de la resolución en caso de pluralidad de deudores incide de manera directa en cómo se afronta el problema de la distribución del perjuicio resolutorio.

Para estos efectos, y por las razones anotadas, en primer lugar se tratará sobre las obligaciones indivisibles (1), para luego tratar las obligaciones simplemente conjuntas o mancomunadas (2), y al final las solidarias (3). Se justifica esta ordenación debido a que se sostendrá que el régimen de las obligaciones indivisibles se rige por la regla general de las obligaciones mancomunadas, de tal suerte que es menester primero dar las razones de esta postura para luego tratar los casos que en realidad estimamos problemáticos, es decir, la distribución del perjuicio resolutorio en las obligaciones mancomunadas y solidarias.

2.1. Exclusión del problema en las obligaciones indivisibles 2.1.1. La regla general: La responsabilidad de los codeudores indivisibles se rige por las reglas de las obligaciones mancomunadas

A nuestro entender, el problema de la pluralidad de deudores e indemnización en caso de resolución únicamente se refiere al campo de las obligaciones mancomunadas y solidarias. No a las indivisibles.

El artículo 1533[1] hace divisible, y por tanto simplemente conjunta, la obligación de pagar perjuicios en caso de incumplimiento de contrato: "Es divisible la acción de perjuicios que resulta de no haberse cumplido o de haberse retardado la obligación indivisible: ninguno de los acreedores puede intentarla y ninguno de los deudores está sujeto a ella, sino en la parte que le quepa".
Según el inciso primero del artículo recién transcrito, la ley traslada el problema de la responsabilidad, en sentido estricto, de las obligaciones indivisibles a las obligaciones mancomunadas. Es decir, incumplida una obligación de carácter indivisible, se dividiría la responsabilidad de los deudores "en la parte que le quepa" a cada uno de estos.

No cabe extrañar esta solución en el Código Civil chileno, ya que la distinción entre obligaciones mancomunadas e indivisibles depende, en principio, de la naturaleza del objeto de la obligación (Peñailillo, 2003, p. 318). Luego, como la indemnización de los perjuicios se refiere normalmente a una suma de dinero (que es de carácter divisible), entonces, la responsabilidad tornaría en mancomunada. La doctrina es conforme con esta interpretación ${ }^{7}$.

En todo caso, el inciso $2^{\circ}$ del artículo 1533 hace responsable de todos los perjuicios a aquel de los codeudores indivisibles que haga imposible el cumplimiento de la obligación respecto de todos, supuesto que se analizará más adelante.

Continuando, el artículo 1533 distribuye la responsabilidad de los codeudores indivisibles en la parte que les quepa en la deuda. El criterio de distribución de la responsabilidad no se refiere a la culpa o dolo de los deudores indivisibles en el incumplimiento, sino en la parte de la deuda que a cada deudor le quepa (Peñailillo, 2003, p. 33). La norma se justifica porque como en la obligación de carácter indivisible no puede cumplirse por partes lo pactado, por la sencilla razón de que la obligación es propiamente indivisible. Entonces, el criterio es objetivo para imputar responsabilidad: la parte en la deuda que le corresponde a cada deudor, pues en la obligación se entiende incumplida por todos.

${ }^{7}$ Por todos: Peñailillo (2003), p. 331. 
Por tanto, la regla general tratándose de una obligación indivisible es que, por la indemnización, los codeudores indivisibles respondan como si fueren deudores mancomunados: el problema de la indemnización de los perjuicios resolutorios en este supuesto debe entonces trasladarse a las obligaciones mancomunadas.

En este tipo de obligaciones, como cada deudor es obligado al todo de la deuda de tal manera que esta no se puede cumplir en parte, entonces el problema de la "divisibilidad" e "indivisibilidad" resolutorias carece de interés. Al incumplir uno de los deudores la obligación, todos pasan a ser incumplidores. Por ello, la ley permite el forzamiento de la constitución de un plazo de gracia al deudor demandado para entenderse con sus demás codeudores indivisibles, ya que la obligación no puede ser cumplida en parte (art. 1530).

\subsubsection{La excepción: Situación del deudor indivisible que} hace imposible el cumplimento de la obligación

A pesar de la regla general, hay dos excepciones que conviene analizar: se trata de los casos del artículo 1533[2] (i) y del artículo $1526 \mathrm{~N}^{\circ} 3$ (ii).

\section{a. Caso del artículo 1533[2]}

Según se ha señalado, en caso de que la obligación fuere indivisible, debería tener aplicación el artículo 1533. La norma hace propiamente divisible la responsabilidad por los perjuicios derivados del incumplimiento de una obligación de naturaleza indivisible.

Ahora, según el artículo 1533[2], si uno de los codeudores indivisibles hace imposible el cumplimiento de los demás, este se hace responsable del total de los perjuicios, y el pago de ellos (de los perjuicios) no se rige por la regla de las obligaciones simplemente conjuntas respecto de los demás codeudores.

El supuesto de hecho contenido en la norma consiste en que hay un codeudor indivisible que hace imposible a los demás el cumplimiento, lo que resultaría quizás contrario a la naturaleza propia de las obligaciones indivisibles, ya que todos se encuentran obligados al pago de la misma prestación, a diferencia de lo que ocurre en caso de obligaciones mancomunadas.
Cabe hacer presente, además, que en este caso cualquiera de los codeudores puede ser demandado por el total puesto que hay unidad en la prestación: hay un solo objeto debido (Peñailillo, 2003, p. 330). E interpelado uno de ellos, puede pedir un plazo para entenderse con los demás (art. 1530). Sin embargo, la ley ha contemplado la posibilidad de que si uno de ellos hace imposible el cumplimiento, solo aquel se hace responsable de todos los perjuicios.

Para entrar en el supuesto contenido en la norma, entonces, deberá probar el deudor demandado que otro de los codeudores por su hecho o culpa ha imposibilitado la prestación debida por todos.

Para graficar la cuestión daremos un ejemplo. Piénsese en un contrato para la confección de una obra material en que los artífices son cuatro. Esta obligación puede ser mancomunada (si la obra es divisible) o bien indivisible si tal ha sido la voluntad de las partes. Si se ha pactado como divisible, es posible que se hayan pactado entregas parciales sucesivas, de tal manera que uno de los deudores entregue una parte, y consecutivamente los otros tres. Así, uno de los deudores pudo haberse obligado a realizar los cimientos de una casa; luego otro, las murallas; el tercero, el techo; y el cuarto, las ventanas. Pero bien podrían las partes pactar indivisibilidad: la casa debe ser entregada en su totalidad, independientemente de que cada uno de los codeudores haya determinado su gestión en el contrato (cimientos, murallas, techumbre, ventanas). En el ejemplo, demandado cualquiera de los deudores distintos de aquel encargado de realizar los cimientos, deberían estos probar que aquel no ha cumplido y ha hecho imposible el cumplimiento de los demás, por lo que podrían excusarse de responsabilidad. Creemos que este es un ejemplo del ámbito de aplicación del art. 1533[2].

Otro tanto resultaría de la obligación indivisible que debe ser cumplida por dos o más codeudores a la vez, supuesto contenido en el artículo 1534. En este caso la ley imputa responsabilidad exclusiva al codeudor que rehúsa o retarda el cumplimiento conjunto (similar en estructura al artículo $1526 \mathrm{~N}^{\circ} 3$ ). 
En estos casos, nuevamente el tema se desliga de las obligaciones indivisibles, toda vez que habrá un solo codeudor responsable, lo que se aleja de la problemática de la pluralidad de responsables.

Ahora, si varios codeudores hicieran imposible el cumplimiento de la obligación, ni el art. 1533 ni el art. 1534 imputan responsabilidad solidaria (a diferencia del artículo $1526 N^{\circ} 3$, que se tratará a continuación), al codeudor que por su hecho o culpa ha retardado o incumplido la prestación. La ley derechamente hace responsable al deudor incumplidor por el todo, con lo que se asemeja a un caso de solidaridad. Esto se da porque son responsables del todo frente al acreedor y este sabrá que hay dos patrimonios en los que puede hacer efectiva la responsabilidad.

\section{b. Caso del art. $1526 \mathrm{~N}^{\circ} 3$}

Sin embargo, Corral parece no estar de acuerdo completamente con la interpretación que se ha propuesto para el artículo 1533, en el sentido de que la responsabilidad de los deudores indivisibles es de carácter mancomunada. Este autor entiende que si se corrige el "defecto de dicción" del art. 1526 № 3 ("aquel", que aparentemente se refiere a un codeudor) permitiría fundar la indivisibilidad de pago de los perjuicios cuando por el hecho o culpa de varios codeudores se hace imposible el cumplimiento de la obligación (2010b, pp. 160-161).

Si interpretamos bien a Corral, este autor entendería que en caso de obligaciones indivisibles todos los codeudores se harían responsables en caso de incumplimiento (siempre que ellos hubieren hecho imposible el cumplimiento), lo que podría ser también conforme a lo dispuesto en el inciso $2^{\circ}$ del artículo 1533.

En efecto, dicha norma hace responsable de todos los perjuicios a aquel codeudor indivisible que ha hecho imposible el cumplimiento de la obligación. Entonces, si hay varios codeudores indivisibles que han hecho imposible el cumplimiento, todos ellos se harían responsables de forma solidaria de la obligación de pagar perjuicios.

Según esto, para Corral, el problema de la legitimación pasiva de los perjuicios en caso de deudores indivisibles, debería trasladarse no a las obligaciones mancomunadas, sino a las obligaciones solidarias, con todas sus consecuencias.

Antes de entrar al fondo de la cuestión, resulta necesario destacar que el mismo criterio de imputación de responsabilidad exclusiva se ha ocupado en dos artículos distintos: en el artículo $1526 \mathrm{~N}^{\circ} 3$ y en el artículo 1533 [2]. En ambos casos se le imputa responsabilidad "solidaria" o "exclusiva" a aquel de los codeudores que haya hecho imposible el cumplimiento de la obligación para los demás.

Asimismo, es importante tener en consideración que el numeral $3^{\circ}$ del artículo 1526 se refiere solo a la indemnización de los perjuicios y no al cumplimiento por equivalente. Entonces, de la pretensión de cumplimiento por equivalente, los deudores mancomunados seguirán siendo obligados de la misma forma, pero no necesariamente de la indemnización de los perjuicios ${ }^{8}$.

\footnotetext{
${ }^{8}$ Para estos efectos, se parte de la base que indemnización de perjuicios no es lo mismo que el cumplimiento por equivalente. La doctrina nacional no está conteste en qué significa propiamente "indemnización de perjuicios". La más clásica doctrina entiende que la indemnización de perjuicios es equivalente a decir "cumplimiento por equivalente o por equivalencia. A título de ejemplo, véase: Gatica (1959), p. 11 y ss; Fueyo (2004), pp. 342-343; Meza (2007), p. 119; Barcia (2008), pp. 111-112; Abeliuk (2014), p. 944. Sin embargo, parte de la doctrina no comparte este fundamento, distinguiendo entre el cumplimiento por equivalente (aestiatio rel), que sería una pretensión de cumplimiento, con la indemnización de perjuicios (id quod interest). En este sentido, Bustamante (2005), pp. 105-126; Corral (2010b), pp. 115-179; Peñailillo (2009), pp. 334-338, pero especialmente Baraona (1997), pp. 159 y ss. De hecho, el mismo Baraona ahí sostiene que la norma en comento, es decir el art. 1533 es una de las normas que consagraría positivamente la distinción efectuada. Nosotros somos conformes con esta interpretación, que, de hecho, se ha ocupado para el análisis de la norma en comento. En todo caso, reconocemos que hay un tercer sector de la doctrina nacional, que entiende que la indemnización de perjuicios debe entenderse en un sentido amplio, que en algunas ocasiones incluye el cumplimiento por equivalencia y en otras no. En este sentido se pronuncia Pizarro al hablar de la "doble función de la responsabilidad contractual" (2010), pp. 299-311; y también en un escrito anterior, Vidal (2007, p. 540); y recientemente López (2015) quien funda toda su teoría de la autonomía de perjuicios en sede contractual en esta misma tesis ya sostenida antes por Pizarro y Vidal.
} 
Con todo, creemos que si bien los artículos $1526 \mathrm{~N}^{\circ}$ 3 y 1533 contienen una misma ratio legis en el sentido de que hacen responsable a aquel deudor que ha hecho imposible el cumplimiento de la obligación a los demás deudores, se aplican a dos supuestos distintos.

A nuestro entender, la primera norma debe referirse, por su ubicación, a un caso de obligación naturalmente divisible, y por tanto pasivamente mancomunada. Debe recordarse que el artículo 1526 trata casos de "indivisibilidad de pago": situaciones en que la obligación es naturalmente divisible (con la excepción del $N^{\circ} 6$ que se refiere a la indivisibilidad de una elección), pero que la ley ha preferido calificar legalmente la obligación de "indivisible" con efectos muy similares a la solidaridad (Peñailillo, 2003, pp. 332-333).

Entonces, el artículo 1526 № 3 se referiría a un caso de una obligación divisible en que uno o más de los deudores mancomunados hacen imposible el cumplimiento de la obligación por los demás. Si bien ello puede ser excepcional en materia de pluralidad de deudores, cabe hacer presente que la calificación de divisible o indivisible de una obligación no solo recae en el objeto de la obligación según el Código Civil, sino que también las partes pueden dar a un objeto debido la calificación de divisible o indivisible (Peñailillo, 2003, p. 320). Volviendo al ejemplo de los deudores de la construcción de una casa, uno de los deudores pudo haberse obligado a realizar los cimientos de una casa; luego otro, las murallas; el tercero, el techo; y el cuarto, a colocar las ventanas. De esta manera, la obligación será de naturaleza divisible. Pues bien, si el primero incumple (los cimientos), hace imposible el cumplimiento de la prestación, a los otros tres (la construcción de los muros, la techumbre y las ventanas). Según el artículo 1526 № 3 solo el obligado a realizar los cimientos sería responsable de todos los perjuicios. Sin embargo, todos son obligados al valor de prestación según su parte o cuota en la deuda si se eligiese la pretensión de cumplimiento por el acreedor, puesto que objetivamente han incumplido frente al acreedor.

Si se está en lo correcto, la norma del artículo 1526 $N^{\circ} 3$, no solo imputa responsabilidad exclusiva al deudor mancomunado que ha incumplido, sino que además permite eximirse de responsabilidad a los demás codeudores mancomunados que por su hecho o culpa no han imposibilitado el cumplimento ya que no son "exclusiva y solidariamente" obligados al pago de los perjuicios según el criterio de la norma en comento.

Ahora, si hay varios deudores mancomunados que han hecho imposible el cumplimiento de los demás, entre estos se justifica que respondan solidariamente del pago de los perjuicios (se trataría de un caso de solidaridad legal) ${ }^{9}$.

Por lo tanto, la situación descrita en el artículo $1526 \mathrm{~N}^{\circ}$ 3 no se refiere a un caso propiamente de indivisibilidad de pago de los perjuicios resolutorios. En el caso en que exista un deudor mancomunado que haga imposible el cumplimiento de la obligación solo este se hace responsable de los perjuicios, y ya no habría una situación de pluralidad de responsables en sentido estricto. Por el contrario, si hay varios de los codeudores mancomunados que hacen imposible el cumplimento de lo demás, deberá redirigirse el problema a la normativa de las obligaciones solidarias que se tratará con posterioridad.

\footnotetext{
Sin embargo, la jurisprudencia de la Corte Suprema no es conforme con la interpretación a la que nosotros adherimos, es decir, que la indemnización contractual no incluye la pretensión de cumplimiento por equivalente, siguiendo con esto el sector más clásico de nuestra doctrina. Dentro de los fallos más recientes, puede citarse en este sentido: Sociedad Rochet y Rochet S.A con Club Deportivo Unión Española (2006); Navarrete con con Empresa Metropolitana de Obras Sanitarias (2008); Plaza con Sociedad Agrícola SACOR Ltda. (2008). A pesar de lo señalado, y tal como se comentará en las próximas líneas, la distinción entre la aestimatio rei y el id quod interest no sólo es útil para determinar lo que sería propiamente la indemnización de perjuicios, sino ayuda a entender el supuesto de hecho de varias normas del Código, en especial, la que comentamos y el artículo 1521 que se analizará con posterioridad.

${ }^{9}$ Por lo tanto, estimamos que no parece justificada la crítica de la doctrina ha efectuado a este artículo. Alguna doctrina ha entendido que estaría demás la expresión "solidariamente" ya que la norma se colocaría en el caso de que un deudor incumpla la obligación. De tal manera que no podría ser solidariamente responsable de sí mismo. Véase, por ejemplo, Meza (2007, p. 87). Sin embargo, este argumento no considera la situación en que exista pluralidad de deudores que hagan imposible el incumplimiento de los demás, de tal manera que ellos sí podrían ser calificados de codeudores solidarios. En este sentido, véase Peñailillo (2003, p. 339).
} 
Puede concluirse, entonces, que en todos los casos de obligaciones indivisibles, la responsabilidad no se rige propiamente por estas reglas, sino que debe reenviarse el estudio a los supuestos de obligaciones simplemente conjuntas y solidarias. Aun en los casos de pluralidad de deudores indivisibles que por su hecho o culpa hacen imposible o retardan el cumplimiento de los demás, se hace innecesaria la categoría de las obligaciones indivisibles para determinar la responsabilidad de los deudores.

Por lo tanto, la legitimación pasiva de la resolución por incumplimiento no juega un papel relevante para el ejercicio de los perjuicios resolutorios en el caso de codeudores indivisibles, toda vez que el problema debe ser reenviado al estudio de las obligaciones mancomunadas y de las solidarias.

\subsection{Mancomunidad pasiva}

Luego de haber estudiado el régimen de la resolución y de los perjuicios en materia de indivisibilidad pasiva, nos abocaremos al estudio de la regla general, cual es la mancomunidad.

\subsubsection{Ejercicio de la acción resolutoria en caso de mancomunidad pasiva}

Como se señaló anteriormente, las tesis de la "divisibilidad" e "indivisibilidad" resolutorias tienen especial aplicación a los casos de mancomunidad pasiva. La tesis de la "indivisibilidad" postula que todos los codeudores mancomunados deben ser demandados de resolución. Por el contrario, la tesis de la "divisibilidad" establece que solo los deudores incumplidores pueden ser demandados de resolución.

El tema dista de ser claro, y las normas del Código tampoco aportan luz sobre esto. Debe tenerse presente que la mancomunidad no fue disciplinada especialmente en la ley por tratarse de la regla general (Meza, 2007, p. 73). En efecto, la solidaridad y la indivisibilidad son tratadas con detalle por el Código como excepciones a la regla general (arts. 1511 y 1524). Más todavía los casos de indivisibilidad de pago (art. 1526), en que la ley impone consecuencias especiales a situaciones que deberían representar divisibilidad y por tanto mancomunidad.
Ahora, también conviene tener presente para los efectos, que se está tratando que la mancomunidad no siempre tiene origen contractual y puede ser derivativa. Por ejemplo, una relación obligatoria de sujeto singular puede derivar en mancomunada por la muerte del deudor cuando existe pluralidad de herederos. La ley no ha dispuesto expresamente este efecto, mas la conclusión se obtiene a partir de su articulado que siempre razona en este sentido: el de la divisibilidad del crédito de pleno derecho entre los herederos (Elorriaga, 2010, p. 598 ss.).

El caso preciso que debe discutirse, entonces, es el de una pluralidad de deudores y que el objeto de la obligación es de naturaleza divisible. Por tanto, la cuestión que hay que resolver es si frente al incumplimiento de cualquiera de los deudores, el acreedor debe pedir la resolución respecto de todos o solo respecto de los incumplidores, y luego, determinar propiamente su responsabilidad. Queda fuera de la problemática el caso de una deuda de sujeto singular, en que posterior al incumplimiento fallece el deudor. Porque condenado el deudor de resolución y perjuicios, esta se transformará en una deuda hereditaria y se liquidará conforme a este régimen. Tampoco cabe confundir esta última situación con el caso del deudor que fallece y transmite la deuda, pero antes del incumplimiento. Como la deuda se divide entonces entre los herederos a prorrata, se presenta de la misma forma que un caso de mancomunidad pasiva originaria.

Delimitado entonces el supuesto de hecho, convendrá tratar el problema del ejercicio de la acción resolutoria en caso de pluralidad de deudores. Dos, a nuestro entender, son las hipótesis que habrá que manejar: $1^{\circ}$ ) caso en que todos los deudores son incumplidores; y $2^{\circ}$ ) caso en que coexisten deudores incumplidores con deudores cumplidores.

En el primer caso propuesto, no hay dudas en que el acreedor podrá demandar la resolución respecto de todos, puesto que son todos deudores incumplidores, sin todavía entrar al problema de la distribución del perjuicio resolutorio. 
El problema que puede darse es si el acreedor solo demanda a algunos de los deudores y no a todos. Esto se puede presentar ya sea en caso en que todos sean incumplidores, o bien cuando coexistan deudores incumplidores con deudores cumplidores (segunda situación). Recordemos que según la teoría de la "indivisibilidad" antes descrita esto no sería posible puesto que como se recordará, la resolución implicaría un acto de disposición del crédito entendido en el marco contractual completo.

Con todo, el caso planteado no debe dejar de analizarse fuera de una relación contractual bilateral. Imaginemos el caso de un vendedor y tres compradores mancomunados, en el que el precio es de 90. Desde el punto de vista pasivo, hay mancomunidad (la obligación de pagar dinero es divisible), por lo que cada deudor es obligado al pago de 30. Entonces, la pregunta es si el acreedor puede demandar a uno de los deudores de resolución y no a los demás. En principio, desde el punto de vista del efecto extintivo de la resolución, parecen no existir reparos para que se solicite la resolución respecto de unos, y a otros el cumplimiento, pues el acreedor en realidad decidiría la extinción de la obligación solo respecto de algunos. En consecuencia, el acreedor elegiría no ejercer su derecho al pago de la prestación dividida por la mancomunidad de deudores. Y, por la otra parte, el deudor demandado no podrá cobrar cuotativamente el crédito que a su vez tiene en contra del acreedor. Sin embargo, habrá que conceder también que el crédito se mantendría vigente respecto de los demás deudores mancomunados quienes podrán exigir su parte o cuota en el crédito, y lo mismo el único vendedor.

Desde el punto de vista de la explicación general de las obligaciones mancomunadas, esta conclusión resultaría generalmente forzosa, cuando el objeto de la obligación del vendedor también es de naturaleza divisible. Porque mirado desde la perspectiva de la pluralidad de compradores (siguiendo el ejemplo dado), hay también mancomunidad activa. Entonces, si lo que se venden son 90 objetos fungibles a un precio también de 90 (1 la unidad) el acreedor tiene derecho a reclamar 30 de cada uno, y si no cumple uno de los compradores, no se ve inconveniente que se demande la resolución respecto de uno de ellos. Es más, podría acudir al mercado para realizar una operación de reemplazo sólo por la parte incumplida.

Más problemático se presenta el caso en que la obligación del vendedor es indivisible, como la entrega de un objeto determinado ${ }^{10}$. Si bien el precio que se paga es de naturaleza divisible, habrá también que conceder que desde el otro lado de la relación obligatoria se configura un caso de indivisibilidad activa. Luego, si uno de los compradores no paga su parte del precio (30), ¿puede pedirse la resolución solo respecto de ese codeudor? Si se observa ahora la cuestión desde el efecto extintivo de la resolución, claramente el acreedor no será obligado a entregar la cosa al comprador incumplidor, y tampoco podrá cobrar la división cuotativa del precio. Sin embargo, como quedaría vigente el resto de las obligaciones, el vendedor estaría obligado todavía a la entrega de la cosa total al resto de los compradores (art. 1527, parte final), pero ellos quedarían obligados solo a la parte del precio que se divide de manera mancomunada (30 cada uno). En este caso, al acreedor no le convendría una resolución parcial subjetiva, por lo que podría demandar a todos de resolución.

Entonces, sin suscribir tesis de la "divisibilidad" resolutoria (por lo menos en los términos planteados por la doctrina), es posible sostener que la solución al problema está en los incentivos legales para el ejercicio de la acción según la naturaleza de las obligaciones bilaterales. Así, cuando hay un caso de mancomunidad pasiva, pero en que ambas obligaciones son de carácter divisible, el acreedor podría optar por una resolución parcial subjetiva y esta elección no perjudicaría a ninguno de los demás deudores no demandados. Por el contrario, cuando la obligación del acreedor es indivisible, probablemente no le convendrá la opción por la resolución parcial subjetiva, y por tanto debería demandar a todos.

${ }^{10}$ No la transferencia del dominio que es propiamente divisible. 
Puede ser, en todo caso, que en el supuesto de obligaciones recíprocas divisibles, tanto al acreedor como a la pluralidad de deudores no le interese una resolución parcial subjetiva, puesto que puede existir interés en el cumplimiento íntegro de la obligación del acreedor. Así por ejemplo, al vendedor podría no interesarle mantener el contrato respecto de dos de los vendedores. Luego, para evitar esta situación, nada impide que se pueda pactar expresamente una "indivisibilidad" resolutoria. Las normas de resolución son supletorias de la voluntad de los contratantes, por lo que no se ven objeciones a un pacto de estas características.

2.2.2. Indemnización de los perjuicios resolutorios en caso de mancomunidad pasiva

Si se está en lo correcto, esto es, que es posible una resolución parcial subjetiva en caso de mancomunidad pasiva, la indemnización de los perjuicios resolutorios puede calcularse independientemente respecto de cada deudor mancomunado.

Volviendo al ejemplo de la venta de 90 bienes determinados a tres compradores por un precio de 1 cada uno, en el que solo uno de los codeudores incumple la obligación del pago del precio, entonces no se ven problemas para que pueda calcularse la indemnización resolutoria de forma independiente respecto de cada uno de los deudores demandados.

Ahora, cuando el acreedor decida demandar a todos y sea procedente la indemnización, habría que calcular esta de acuerdo a la parte incumplida por cada uno de los deudores, y efectuar cálculos separados.

\subsection{Solidaridad pasiva}

Por último, queda la tercera clase de pluralidad de sujetos, la solidaridad pasiva. Siguiendo el mismo esquema anterior se analizará el ejercicio de la acción resolutoria, para luego analizar el problema de los perjuicios.
2.3.1. Ejercicio de la acción resolutoria en caso de solidaridad pasiva

En un contrato bilateral puede establecerse que los deudores adquieran el carácter de solidarios. Por ejemplo, en un contrato de compraventa en que el precio debe ser pagado por los tres compradores in solidum.

La cuestión que primeramente debe analizarse es si frente al incumplimiento de cualquiera de los codeudores solidarios debe demandarse a todos los codeudores o bien solo puede demandarse a alguno de ellos de resolución. La cuestión, al igual que en la mancomunidad pasiva, tiene importancia para determinar cuál es su responsabilidad (en sentido estricto) por los perjuicios resolutorios.

Se ha señalado hasta esta parte que la solución en las obligaciones mancomunadas es que cada deudor debe ser demandado independientemente de resolución por incumplimiento, y asimismo, responde por su parte o cuota en la deuda.

Sin embargo, la misma solución no es fácilmente traspasable a un caso de solidaridad pasiva, toda vez que existe precisamente un pacto de solidaridad en que los deudores (solidarios) no se han obligado a una parte de la deuda, sino que se han obligado al pago total de la misma.

Por tanto, la pregunta es si debe demandarse a todos los codeudores solidarios de resolución o no, y según las respuestas que se den a esta pregunta, se hace necesario determinar cómo responden los codeudores solidarios.

a. Función de caución de la solidaridad pasiva y su relación con la resolución por incumplimiento

Cabe considerar que la solidaridad pasiva no es solamente una modalidad que puede tomar las obligaciones en caso de pluralidad de sujetos, sino representa la caución personal más importante: permite exigir el total de la obligación al deudor que se ha obligado como tal, tenga o no interés en la deuda. 
Lo anterior es digno de ser tenido en consideración, ya que el acreedor tiene varios patrimonios en los cuales puede hacer efectiva la acción de cumplimiento, incluso forzado. En todo caso, debe tratarse de una obligación de carácter divisible, puesto que de lo contrario, a pesar de un pacto de solidaridad, la obligación torna en indivisible, como se desprende de los artículos 1521 y 1524.

Es bastante claro que la solidaridad se extiende por lo menos en lo tocante a la acción de cumplimiento. La misma ley señala que en caso de solidaridad "puede exigirse a cada uno de los deudores o por cada uno de los acreedores el total de la deuda" (art. 1511) [La cursiva es nuestra].

La cuestión que queda por resolver es qué sucede en el caso en que el acreedor no decida hacer uso de su opción de cumplimiento sino de la facultad resolutoria contenida en el artículo 1489, con perjuicios. ¿Cumple la solidaridad la misma función de caución frente a la resolución por incumplimiento, particularmente de la indemnización de los perjuicios?

b. Ejercicio de la acción resolutoria en contra de codeudores solidarios

A pesar de que la ley nada dice sobre el particular, parece que la mecánica propia de la solidaridad pasiva sería contraria a una divisibilidad resolutoria. Por ejemplo, si por la obligación del pago del precio en una compraventa existiesen tres codeudores solidarios incumplidores, el acreedor debería solicitar la resolución del contrato respecto de todos y no solamente respecto de un deudor incumplidor.

La cuestión se presenta de forma distinta que en la mancomunidad para aquella teoría que sigue la divisibilidad resolutoria. Si se admitiese la divisibilidad resolutoria, habría que aceptar que cuando el acreedor solicite la resolución del contrato en contra de uno de los codeudores solidarios, la solidaridad se mantendría respecto de los demás codeudores y, por tanto, el acreedor podría exigir el cumplimiento total de la obligación a los demás.

Sin embargo, una solución como la enunciada nos parece que no es correcta. Tratándose de cualquiera de los codeudores solidarios, no debe hablarse del incumplimiento de una de las obligaciones, sino más bien del incumplimiento de todos los codeudores ${ }^{11}$. Cuando un codeudor incumple, lo hacen también los demás (siempre que estén obligados al mismo plazo o condición). Es decir, a diferencia de lo que ocurre en la mancomunidad pasiva en que existe pluralidad de prestaciones debidas, en la solidaridad hay una sola prestación debida por dos o más deudores y por el total de ella, no siendo admisible la divisibilidad en el pago ${ }^{12}$.

Por ello resultaría del todo extraño que se pudiera demandar separadamente a uno de los codeudores de resolución (con perjuicios) y a los demás por el cumplimiento, a diferencia de lo que pudiera ocurrir en un caso de mancomunidad pasiva si se siguiere la tesis de la divisibilidad resolutoria.

\subsubsection{Indemnización de los perjuicios resolutorios en caso de solidaridad pasiva}

Entendiendo que debe demandarse a todos los codeudores solidarios de resolución ya que el incumplimiento de uno de ellos acarrea el incumplimiento de los demás, cabe entonces abocarse al problema de los perjuicios resolutorios. La pregunta es la siguiente: ¿responden los codeudores solidarios de la acción por perjuicios resolutorios, asimismo, de forma solidaria? Dicho de otra manera: ¿se mantiene la solidaridad para los efectos de los perjuicios resolutorios?

a. La distinción legal entre la aestimatio rei y el id quod interest y la responsabilidad solo del deudor "culpable o moroso"

El Código Civil contiene una norma que regula aparentemente de forma suficiente el tema. Esta es el artículo 1521: "Si la cosa perece por culpa o durante

\footnotetext{
${ }^{11}$ En el mismo sentido Clemente (1998, p. 293). Así también se ha pronunciado la Corte Suprema en una oportunidad: Ramírez con Ruíz Tagle (1953).

12 Por todos: Peñailillo (2003, p. 254).
} 
la mora de uno de los deudores solidarios, todos ellos quedan obligados solidariamente al precio, salva la acción de los codeudores contra el culpable o moroso. Pero la acción de perjuicios a que diere lugar la culpa o mora, no podrá intentarla el acreedor sino contra el deudor culpable o moroso".

La norma hace una distinción importante: distingue entre la obligación perpetuada y la indemnización de los perjuicios, siguiendo la regla general del artículo 1672 (Baraona, 1997, p. 159). Así, la parte primera del artículo en comento claramente mantiene la solidaridad sobre la obligación perpetuada por el incumplimiento de los codeudores solidarios. Nótese que la ley mantiene la solidaridad porque en realidad a lo que se está refiriendo esta parte del precepto es a la ejecución por equivalencia de la prestación debida: "el precio". Empero, el supuesto debe extenderse no solo a los casos de perecimiento de la cosa, sino también a otros supuestos de incumplimiento contractual (Somarriva, 1943, p. 65, n. 80).

En cambio, respecto de la indemnización de los perjuicios, el legislador ha preferido guardar otra regla: solo se hace responsable el "deudor culpable o moroso" del perecimiento de la cosa.

b. ¿Quién es el codeudor solidario "culpable o moroso" del art 1521?

Se ha señalado unas líneas atrás que en caso de solidaridad, el incumplimiento de uno de los deudores solidarios, es en realidad incumplimiento de todos. Según lo dicho, en principio, todos los codeudores solidarios serían culpables o morosos, puesto que el incumplimiento de uno de los codeudores acarrearía el incumplimiento de los demás.

Sin embargo, si esta fuera la solución, entonces el artículo 1521 estaría de más. En efecto, hubiera bastado con que la primera parte del artículo hubiera establecido el mantenimiento de la solidaridad tanto para el valor de prestación (la obligación perpetuada) como de la indemnización de los perjuicios. No obstante, la segunda parte del artículo reduce el campo de aplicación de la acción por perjuicios respecto de los codeudores "culpables" o "morosos". No son todos responsables, sino solamente aquel o aquellos que puedan ser calificados como tal o tales.

Esto permite sostener que en la solidaridad el incumplimiento de al menos uno de los codeudores solidarios puede ser calificado de culpable o moroso y excluya la responsabilidad de los demás.

La distinción no deja de ser interesante, puesto que la ley ha colocado dentro de la esfera de los riesgos patrimoniales de todos los codeudores solidarios solo el valor de prestación, mas no los perjuicios, que se imputarán a un deudor específico: el culpable o moroso.

La norma, por tanto, distingue dos hipótesis en las que un codeudor solidario se hará responsable por los perjuicios: aquel que ha incumplido el contrato con culpa (1) y, el que se ha constituido en mora (2).

\section{i. El codeudor solidario "culpable"}

Según el tenor literal del art. 1521, el deudor "culpable" será aquel que se le pueda imputar el perecimiento de la cosa. La norma está pensada, por lo tanto, para el caso de deuda solidaria de objetos específicos, puesto que si la deuda solidaria fuera de género el art. 1521 no es aplicable (el género no perece). Más todavía, debe tratarse de objetos específicos divisibles, porque de lo contrario la obligación tornaría en indivisible.

Entonces, frente al perecimiento de la cosa debida solidariamente, el art. 1521 operaría de la siguiente forma: a) el acreedor demandará a todos los codeudores solidarios por el precio y la indemnización de los perjuicios (si se tratase de cumplimiento); b) aquellos codeudores solidarios que estimen que no han provocado el perecimiento de la cosa se defenderán señalando que solo serán obligados al "precio", mas no a la indemnización de los perjuicios; c) el tribunal deberá determinar quién es el codeudor solidario a quien debe imputarse el perecimiento de la cosa para la condena de perjuicios.

Ahora, frente a las dificultades probatorias de quién es este codeudor "culpable" del perecimiento, debe aplicarse el art. 1671: "Siempre que la cosa perece en poder del deudor, se presume que ha sido por hecho o por culpa suya". Debida la cosa solidariamente por 
todos los codeudores solidarios, debe presumirse que todos la han incumplido. De aquí es que hay un principio de responsabilidad solidaria respecto de todos los codeudores solidarios.

Entonces, si todos los codeudores solidarios fueren legalmente responsables, la presunción de perecimiento culposo se les aplicaría a todos por el solo el hecho del incumplimiento de cualquier codeudor solidario. La consecuencia a la que pudiera llegarse en este supuesto es que la indemnización sería debida por todos los codeudores, por el total. Si así fueren las cosas, importaría poco pensar que se traspasaría la solidaridad a la indemnización (en los efectos externos de la solidaridad, por lo menos), porque los codeudores solidarios serían responsables por el todo.

Por lo tanto, cabrá cuestionarse cuáles son los posibles casos en que los codeudores solidarios pueden escapar a la presunción del art. 1671.

En primer lugar, es posible teorizar sobre casos en que algunos codeudores solidarios hayan incumplido la obligación (el perecimiento), y otros que no. Particularmente nos referimos a aquellos casos en que los codeudores solidarios se encuentran obligados a plazos o condiciones distintos, cuestión que es admitida por nuestro Código (art. 1512). En tal caso, es lógico que aquellos codeudores cuya obligación no sea actualmente exigible al tiempo del perecimiento no sean responsables de ello.

Bien también cabe pensar en aquellos casos en que se produce imposibilidad inimputable del deudor (caso fortuito), pues en tal caso, si bien hay objetivamente incumplimiento, no habría la imputabilidad exigida por la norma (Caffarena, 1980, p. 362).

Sin embargo, no deja de ser relevante que la ley imputa responsabilidad solo a los codeudores culpables, lo que hace presumir que, frente a un incumplimiento contractual de uno de los codeudores, podría presentarse la hipótesis de concurrencia de codeudores culpables y no culpables a pesar de las excepciones que hemos mencionado. De lo contrario la norma no tendría sentido, ya que hubiera bastado con el establecimiento de las normas generales.

\section{ii. El codeudor solidario "moroso"}

Otro tanto sucede con la mora del deudor. En principio, según la opinión generalizada de los autores, la constitución en mora de uno de los codeudores solidarios acarrea la constitución en mora de los demás ${ }^{13}$. Pero nuevamente argumentamos que el Código solo imputa responsabilidad a algunos de los codeudores y no a todos (solo al codeudor "moroso").

Se recordará que la mora del deudor, dentro de varios efectos, tiene la virtud de colocar el riesgo del perecimiento de la cosa en manos del deudor, de tal suerte que aun frente a un caso fortuito, la obligación se perpetúa ${ }^{14}$. De esta manera, el caso fortuito sobrevenido durante la mora del deudor no extingue la obligación (Abeliuk, 2014, pp. 976-977). Por lo tanto, estando todos los codeudores obligados a plazos idénticos (art. $1551 \mathrm{~N}^{\circ} 1$ y 2), o bien ya interpelados judicialmente (art. $1551 \mathrm{~N}^{\circ} 3$ ), si acaece un caso fortuito que produce el perecimiento de la cosa, entonces, se hacen responsables de los perjuicios. Consiguientemente, no serán responsables aquellos codeudores cuyo plazo no había vencido al momento del acaecimiento del caso fortuito, o bien, en los demás casos cuando no habían sido interpelados de pago.

En conclusión, si la ley ha imputado responsabilidad solo a algunos de los codeudores solidarios (el "culpable o moroso"), es necesario determinar qué codeudores solidarios pueden hacerse responsables por la culpa o mora en el incumplimiento, lo que supone precisamente que hay codeudores que no responden por los perjuicios en la técnica del Código.

De lo anterior se deduce que no todos los codeudores solidarios son garantes de la actuación de los demás

${ }^{13}$ Por todos, Peñailillo (2003, pp. 286-287).

${ }^{14}$ Para un repaso histórico del efecto perpetuador, véase Díez-Picazo (1996, pp. 81-82). 
codeudores por la indemnización de perjuicios, sino solamente limitados al valor de prestación (Peñailillo, 2003, p. 283 $)^{15}$. En esto sigue el Código a Pothier ${ }^{16}$, al (hoy antiguo) Código Civil francés (art. 1205)17, y al proyecto de García Goyena (art. 1165) ${ }^{18}$. Asimismo, esto se diferencia de lo que sucede en el derecho español y argentino en que se obliga y hace responsables a todos los codeudores solidarios por el incumplimiento (Caffarena, 1980, pp. 368-369).

c. Incidencia de la distinción entre codeudor solidario interesado y no interesado para la responsabilidad del deudor culpable o moroso de art. 1521: la exclusión del codeudor solidario "no interesado"

Para la determinación de aquellos codeudores solidarios que sí se hacen responsables por la indemnización de perjuicios y aquellos que no, puede acudirse a la distinción entre codeudor "interesado" y codeudor "no interesado". Si bien todos se obligan solidariamente, los segundos concurren garantizando la obligación prestando su patrimonio para la seguridad de a quien verdaderamente le interesaba el crédito. La ley ha regulado los efectos entre estos codeudores solidarios en el art. 1522, que es el artículo posterior al supuesto que se viene analizando (art. 1521).
El artículo 1522, en principio, se refiere solo a los efectos ulteriores al pago de una obligación por un codeudor solidario. Y así, si paga un codeudor interesado, se subroga el en el crédito, pero se extingue la solidaridad (inc. $1^{\circ}$ ), y podrá redirigirse contra los demás codeudores interesados por su parte o cuota en la deuda. Sin embargo, si hubieren concurrido además codeudores no interesados, estos son reputados como fiadores (inc. $2^{\circ}$ ).

La norma en comento hace una distinción aclarando que el codeudor solidario no interesado no tiene parte o cuota en la deuda, puesto que solo ha concurrido a la deuda para caucionarla. En efecto, solo presta su patrimonio para la seguridad de una deuda ajena, al igual que el fiador, con la diferencia de que se obliga por el total de la misma sin excusión ni división (el fiador goza del beneficio de excusión y de división). La cuestión es si este codeudor no interesado, además de estar obligado a la deuda (o al valor de prestación, "el precio"), es además responsable por la misma (a la indemnización de los perjuicios).

De la regulación del Código aparece claro que el codeudor solidario no interesado es por lo menos obligado a la prestación. En efecto, el acreedor gozará de la acción

\footnotetext{
${ }^{15}$ Sin embargo, la norma no ha estado exenta de críticas: Somarriva (1943, pp. 64-66).

${ }^{16}$ Explicaba Pothier en su Tratado de las Obligaciones la regla que se viene comentando: "Adviértase el hecho, la culpa o la tardanza de uno de los codeudores solidarios obliga en realidad á los demás ad conservadam et perperpetuandam obligationem, en cuanto a no quedan libres de su obligación por la pérdida de la cosa, y deben pagar su valor; y por esto dice la ley punult. ff. de deubus rei: alterius factum alteri quoque nocet: pero no es menos cierto que esta culpa, hecho o tardanza no puede perjudicarles ad augendam ipsorum obligationem, es decir, que en cuanto á los daños y perjuicios que puedan resultar de la falta de cumplimiento de la obligación ultra del valor de la cosa debida, no hay otro obligado que aquel que ha cometido la culpa ó tardanza. La obligación del otro ú otros deudores que no han cometido falta alguna ni incurrido en demora puede perpetuarse, pero en manera alguna aumentarse; y por esto si bien deben pagar el valor de la cosa que ha perecido, nada tienen que ver con los daños y perjuicios que la culpa o tardanza del otro haya podido acarrear, y por lo mismo este será el único obligado á su reparación. En este sentido dice la ley 32 §penult. ff. de usuris: Si duo rei promittendi sint, alterius mora alteri non nocet" (1839, §274).

${ }^{17}$ Art. 1205 Código Civil Francés: "Si la chose due a péri par la faute ou pendant la demeure de l'un ou de plusieurs des débiteurs solidaires, les autres codébiteurs ne sont point déchargés de l'obligation de payer le prix de la chose; mais ceux-ci ne sont point tenus des dommages et intérêts.

Le créancier peut seulement répéter les dommages et intérêts tant contre les débiteurs par la faute desquels la chose a péri, que contre ceux qui étaient en demeure".

${ }^{18}$ Decía el comentario de García Goyena al art. 1165 de Proyecto: "Sería injusto que la falta o mora de uno de los codeudores aprovechase a los otros para libertarse de la obligación y enriquecerse; pero no lo sería menos que les perjudicase para agravarla.

Así es como se esplica [sic] y concilia con las leyes citadas la 18, título 2, libro 45 del Digesto: Ex duobus reis ejusdem Stichi promittendi factis, alterius factum alteri quoque nocet: daña para perpetuar la obligación, no para aumentarla o gravarla. Podrá, pues, el acreedor el acreedor pedir el precio de la cosa a los otros co-deudores, salvo el recurso de estos contra el culpable ó moroso, pero no los perjuicios é intereses que constituyen una nueva obligación tan personal como lo es la culpa ó la mora.

Sin embargo, cuando se ha estipulado expresamente el resarcimiento de perjuicios é intereses para el caso de inejecución ó falta de cumplimiento, la responsabilidad debe ser mancomunada [debe entenderse solidaria, puesto que García Goyena llamaba mancomunidad a la solidaridad], salvo el recurso de los inculpables contra el moroso ó culpable.

Yo tengo por legal y justa esta opinión, y como arreglada a la voluntad e intención de las partes” (1852, III, p. 100).
} 
de cumplimiento en contra de este como de cualquier codeudor solidario, y el no interesado no goza ni de los beneficios de excusión ni de división propios del fiador.

De su estatuto de codeudor solidario, puede el acreedor ejercer la acción resolutoria en contra de este. Sin embargo, el problema es si resulta responsable por los perjuicios resolutorios, ya por su propio incumplimiento, ya por el incumplimiento de un codeudor interesado.

A nuestro entender, este codeudor no interesado debería tener un estatuto similar tanto al fiador como al tercer poseedor de un bien prendado o hipotecado, salvo que a diferencia de estos dos últimos casos el codeudor solidario no se obliga propter rem (como en la prenda y en la hipoteca) sino con todo su patrimonio.

En los casos descritos recientemente, tanto el fiador como el tercer poseedor de la cosa prendada o hipotecada son responsables por la prestación, no por la indemnización de los perjuicios. Así, el fiador se obliga a la prestación en los mismos términos del deudor principal, pero subsidiariamente a él. La relación entre acreedor y fiador (en este sentido directa), no dice relación con la acción de perjuicios resolutorios, ya que lo que garantiza el fiador es el cumplimiento (oportuno, ex art. 2347) de la obligación ${ }^{19}$. Pero de los perjuicios que derivan de la resolución no debiera responder, ya que no es el deudor del contrato que da lugar precisamente a la resolución. Otro tanto sucede con el tercer poseedor de la cosa prendada o hipotecada. La caución garantiza el cumplimiento (también oportuno) de la obligación, mas no la indemnización de los perjuicios compensatoria (art. 2402).
A nuestro entender, en la misma situación se encuentra el codeudor no interesado. Si bien el Código nada dice sobre el particular, la aplicación práctica del artículo 1522 del Código Civil permite sostener que el codeudor solidario no interesado no se hace responsable por los perjuicios resolutorios.

Si se relaciona el supuesto de hecho preciso del art. 1521 con el artículo 1522, se llega a esta conclusión. Debe recordarse que el art. 1521 solo imputa responsabilidad solidaria por el precio no por la indemnización de los perjuicios, de la que solo responde el deudor culpable o moroso. Luego, en un caso de una prestación solidaria de una cosa divisible pueden existir deudores solidarios interesados y deudores solidarios no interesados. Ahora, imaginemos que perece la cosa divisible en manos de un codeudor solidario interesado (deudor culposo). En este caso, el acreedor tendrá la acción por el precio contra todos los deudores solidarios (art. 1521). Sin embargo, la acción de perjuicios solo la podrá ejercer en contra del codeudor "culpable". ¿Son los codeudores solidarios no interesados "culpables" del perecimiento de la cosa? Si la ley los reputa como fiadores, para sus efectos internos (art. 1522), por expresa disposición de la ley debe entenderse que responden solo del cumplimiento oportuno de la obligación (art. 2347). Es decir, deben el precio y la indemnización moratoria (el accesorio). En esto habría correspondencia.

Pero ¿si el acreedor decidiera optar por la resolución? ¿Responden de estos perjuicios los codeudores solidarios no interesados? En primer lugar, cabrá señalar que no hay responsabilidad solidaria por el precio, puesto que no es parte de la pretensión del actor. El problema que queda por resolver es el de los perjuicios resolutorios.

\footnotetext{
${ }^{19}$ Al opinar sobre la disposición, Somarriva no es del todo preciso para un caso de resolución con perjuicios: "Por ser un accesorio a la deuda, se entiende que el fiador también responde al acreedor de la indemnización de perjuicios ya sea por el incumplimiento o por el incumplimiento tardío de la obligación por parte del deudor" (1943, p. 121). Sin embargo, creemos que piensa en la indemnización de perjuicios que sigue a la pretensión de cumplimiento, puesto que la obligación del fiador debe consistir en el pago de una suma de dinero (pp. 107-108). Por esta razón, es que si la fianza es limitada, solo responde hasta la limitación, excluidos los perjuicios moratorios (intereses) (pp. 123-124). Por el contrario, si la fianza es ilimitada, respondería de los perjuicios moratorios como accesorios al valor de prestación. En esto el Código siguió al CCFra en su antiguo art. 2016 (hoy art. 2293), que establece el mismo criterio. Esto se desprende de una nota expresa que Bello dejó al art. 2347 en comento, en que también dejó constancia de haber seguido a Rogron, Delvincourt y Pothier. Con todo, ni de las lecciones de Pothier (1839, §§ 405-406), Delvincourt (1825 VII, p. 346), ni Rogron (1843, p. 492), se desprende un caso claro de resolución con perjuicios.

Hay, sin embargo, un argumento de texto que permite sostener que el fiador no responde por los perjuicios resolutorios: según el tenor literal del art. 2347 la fianza se extiende a los accesorios de la deuda, y la indemnización por los perjuicios resolutorios no lo es.
} 
Entendiendo que concurren codeudores solidarios interesados y no interesados, solo los primeros tienen deber de prestación, no los demás que vienen solo en caucionar la obligación (por el precio).

Estimamos, entonces, que estos codeudores por tanto deben excluirse de la indemnización resolutoria. El acreedor, antes de ejercer el remedio debería tener en consideración la distribución de riesgos que apareja el ejercicio del mismo: si le es más conveniente ejercer la pretensión de cumplimiento solidariamente en contra de todos los codeudores solidarios (interesados o no), o bien la resolución con indemnización y solo esta última contra los codeudores solidarios interesados.

Para confirmar la hipótesis, se propone ahora colocar otro ejemplo en el que no exista perecimiento de la cosa. Es posible afirmar que se produce el mismo resultado teórico. Imagínese, para estos efectos, un contrato de compraventa en que el precio (100) se debe solidariamente por cuatro codeudores solidarios, dos interesados y dos no interesados. Si pagara un codeudor no interesado, se subroga en los derechos del acreedor (art. $1610 \mathrm{~N}^{\circ} 3$ ), por lo que conservaría la acción de cumplimiento como la acción resolutoria en contra de los demás codeudores solidarios (art. 1612, conserva "todas" las acciones). Sin embargo, a este respecto debería ser aplicable el artículo 1522 que se coloca en la situación en que un codeudor solidario no interesado pague la deuda. Se subroga en los derechos del acreedor, y puede ejercer la acción resolutoria en contra de los demás codeudores solidarios (principalmente le puede ser útil por el efecto restitutorio de la resolución más la indemnización de los perjuicios, que podría ser más conveniente que la acción de cumplimiento). No hay duda de que puede ejercer la acción de perjuicios resolutorios en contra de los codeudores solidarios interesados. ¿Y respecto del codeudor solidario no interesado?

La respuesta creemos que debe ser negativa por dos razones. Primero, porque la ley califica al codeudor no interesado como fiador, de tal manera que no respondería por los perjuicios de esta clase, sino solo por los moratorios (art. 2347). Y en segundo lugar, porque no sería culpable o moroso. La calificación de fiador de este codeudor solidario no interesado lo excluye de las consideraciones de la culpa y de la mora (propias de la responsabilidad contractual), ya que únicamente se obliga al cumplimiento de la obligación (solidariamente).

Por tanto, a nuestro entender, los codeudores solidarios no interesados no se hacen responsables de los perjuicios resolutorios ya que no puede calificárseles de deudores "culposos o morosos" en los términos del artículo 1521 parte final.

Puede objetarse a nuestra postura, señalando que la distinción entre codeudor solidario interesado y no interesado se aplica solo a los efectos internos de la solidaridad (entre los propios codeudores, de contribución a la deuda), más no a los efectos externos de la solidaridad (entre los codeudores y el acreedor, de obligación a la deuda). Sin embargo, es posible que el acreedor tenga noticia de la calidad de los codeudores por el contrato, ya sea porque expresamente así se ha pactado en el contrato, o bien, porque de la naturaleza de la obligación caucionada se desprende la calidad de codeudores no interesados. A falta de pacto contractual, debe entenderse desde el punto de vista externo de la solidaridad que todos los codeudores solidarios deben ser considerados como interesados.

Para graficar el planteamiento se propondrá como ejemplo dos sentencias en que se ha condenado a los perjuicios resolutorios a los codeudores solidarios. Sin embargo, se sostendrá que solo el primero de los casos fue correctamente fallado por la Corte Suprema, en cambio el segundo no lo fue, porque desconoció a los codeudores solidarios no interesados.

El primero de los casos que es posible traer a colación es Zamora con Atalah y otros (2002). Este pleito resolutorio tiene su origen en el incumplimiento de los promitentes compradores (obligados solidariamente) de pagar el adelanto del precio en una promesa de compraventa. La Corte Suprema termina en este caso 
condenando solidariamente al pago de los perjuicios resolutorios, que consistieron básicamente en perjuicios extrapatrimoniales.

El segundo de los casos es Fisco de Chile con Descouvieres y otros (2004). El pleito resolutorio tuvo origen por el incumplimiento de un becario de su obligación de realizar la práctica obligatoria que exigía precisamente su contrato de beca. Razón por la que el Fisco de Chile decide instar la resolución del contrato de beca, y exigir a título de perjuicio resolutorio el valor total de las cantidades pagadas al becario, pero también contra los dos codeudores solidarios del becario, avalistas en los pagarés firmados en virtud del contrato.

Tienen en común los casos enunciados, que hay sujetos que se han obligado solidariamente al pago de una suma de dinero. En Zamora, al adelanto del precio de un contrato de promesa de compraventa; y en Fisco de Chile, al pago de una suma contenida en un pagaré. Con todo, la calidad de los deudores es distinta y claramente identificable en el pacto contractual. En Zamora, los demandados pactaron solidaridad como deudores del adelanto del precio en su calidad de promitentes compradores. Es decir, eran codeudores a los que les interesaba el negocio: codeudores solidarios interesados. En cambio, en Fisco de Chile solo el deudor principal, el becario demandando, es codeudor solidario interesado. Del pagaré firmado anexo al contrato de beca resulta claro que los demás, los avalistas, a los que la sentencia los califica de deudores solidarios, serían claramente no interesados: solo concurrieron al pacto contractual garantizando el deber de cumplimiento del deudor principal (la beca).

Probablemente, el yerro de la Corte Suprema en la condena solidaria de los avalistas en Fisco de Chile se vio ayudada por la confusión entre el efecto restitutorio de la resolución (la devolución de los dineros pagados al becario en virtud del contrato de beca) y la indemnización de los perjuicios resolutorios ${ }^{20}$. Ahora, si se despeja el error conceptual en el que incurrió el fallo, la pregunta sigue vigente: ¿tienen legitimación pasiva de la acción por perjuicios resolutorios estos avalistas (codeudores solidarios)? Creemos que no. Imagínese que uno de los avalistas hubiese pagado el importe del pagaré al acreedor. Si su situación fuere regida por la de las obligaciones solidarias, habría que conceder que el avalista se subroga en los derechos del acreedor. Entonces, se produciría la situación en que podría exigir el cumplimiento del contrato (su equivalencia, el monto consagrado en el pagaré), o bien la resolución del contrato. Mas, en este caso el único culpable o moroso puede ser el becario incumplidor, no el otro avalista quien por el carácter no fungible de la obligación del becario (realizar la práctica profesional) no puede cumplir la obligación. Por esta razón, estimamos que por aplicación de los arts. 1521 y 1522 solo pueden ser deudores "culpables" o "morosos" los codeudores solidarios interesados, puesto que solo ellos pueden dar cumplimiento a la obligación. No los codeudores solidarios no interesados, quienes solo caucionan el cumplimiento y los perjuicios anexos a dicha pretensión (moratorios).

A pesar de la exclusión de responsabilidad del deudor solidario no interesado por los perjuicios resolutorios, es posible extenderla por pacto contractual expreso a esta indemnización. Nada impide que a través del pacto contractual se pueda hacer responsable al codeudor solidario no interesado de forma solidaria. De esta manera, la estipulación de esta cláusula se asemejaría mucho a una cláusula penal constituida por un tercero establecida expresamente para el caso de resolución ${ }^{21}$.

d. ¿Se mantiene la solidaridad en la responsabilidad por los perjuicios resolutorios tratándose de codeudores interesados?

Como ya se ha señalado, solo están legitimados para ejercitar la acción por los perjuicios resolutorios en contra de los codeudores solidarios interesados, quienes responden ex art. 1521 del Código Civil. Ahora cabe resolver si la indemnización por la que son responsables estos codeudores se mantiene de forma solidaria, o bien, si se debe de forma simplemente conjunta.

20 Sobre esta distinción, véase Contardo (2015, pp. 171-191).

${ }^{21}$ Sobre la cláusula penal para un caso de resolución véase especialmente Corral (2010a, p. 258 ss.). 
Por lo pronto, tiene solamente interés el apartado en caso de pluralidad de codeudores interesados, toda vez que no tendrá importancia en caso en que exista un codeudor solidario, ya que nada solidariamente deberá.

La respuesta, a nuestro entender, es que la indemnización por los perjuicios resolutorios dependerá de la conducta que desplieguen los codeudores interesados.

i. Caso de pluralidad de codeudores solidarios interesados que hagan imposible el cumplimiento de la obligación respecto de otros codeudores solidarios

Se trata del caso ya analizado del artículo 1526 № 3.

$\mathrm{Si}$ bien el caso naturalmente se aplica a las obligaciones mancomunadas, no vemos razones para que no pueda ser aplicado a un caso de solidaridad. Es necesario recordar que según este artículo todos los deudores se hacen responsables de la indemnización por el todo. Y, llegando a la conclusión que para los efectos externos los codeudores mancomunados son solidariamente responsables ("es exclusivay solidariamente responsable"), deberían todos los codeudores que hacen imposible el cumplimiento de los demás, ser responsables también solidariamente. Es decir, en este caso, la solidaridad se mantendría para los efectos de la indemnización, solo respecto de los codeudores que hacen imposible el incumplimiento de los demás.

ii. Caso de pluralidad de codeudores solidarios interesados que no hagan imposible el cumplimiento de la obligación respecto de otros codeudores solidarios

Este caso sería la regla general. Se trata de la situación en que existirían varios codeudores solidarios interesados, y ellos no han cumplido sus obligaciones. No se trata de la situación descrita en el apartado anterior, sino que hay inactividad de los codeudores en el cumplimiento, pero no implica la imposibilidad de cumplimiento de los demás.

Cabe de nuevo recordar que el Código chileno siguió sobre el particular las enseñanzas de Pothier, al Código Civil Francés y a García Goyena, a diferencia de otros códigos que prefirieron mantener la solidaridad para efectos indemnizatorios de manera expresa.

Si el incumplimiento de uno de los codeudores solidarios interesados acarrea el incumplimiento de los demás codeudores solidarios, entonces, son todos los codeudores solidarios interesados culpables o morosos del incumplimiento, y en consecuencia, responsables ex art. 1521.

También cabe hacer presente, al igual que en lo que sucede en el art. $1526 \mathrm{~N}^{\circ} 3$, que la ley no ha establecido un mantenimiento de la solidaridad para el caso de los perjuicios, sino sólo de la acción de cumplimiento (art. 1521, parte $1^{\mathrm{a}}$ ). Sin embargo, al acreedor le será indiferente si la obligación es solidaria o no, puesto que podrá cobrar el total de los perjuicios respecto de todos.

\section{Conclusiones}

A partir de lo expuesto en los apartados precedentes, arribamos a las siguientes conclusiones:

1. Frente a la situación de pluralidad de deudores, la doctrina nacional no está conteste si la resolución del contrato debe provocarse respecto de todos ellos (la "indivisibilidad resolutoria"), o bien puede provocarse respecto de alguno de ellos (la "divisibilidad resolutoria"). Dependiendo de la tesis que se siga, se presentan importantes consecuencias en lo tocante a cómo se distribuye el perjuicio resolutorio.

2. Sin embargo, para el análisis del problema presentado, conviene distinguir entre los casos de indivisibilidad, solidaridad y mancomunidad pasiva, puesto que no en todos los casos resulta forzoso demandar a todos los codeudores de resolución por incumplimiento, y por tanto, no existe una regla uniforme para la distribución del perjuicio resolutorio en los casos de pluralidad de deudores.

3. Tratándose de la indivisibilidad pasiva, por aplicación del art. 1533 del Código Civil, el problema de la distribución del perjuicio resolutorio debe reconducirse al de las obligaciones mancomunadas, ya que la Ley por su expresa disposición le otorga el carácter de divisible a la indemnización. Sufren excepción a esta regla, 
los supuestos contenidos en los artículos $1526 \mathrm{~N}^{\circ} 3$ y 1533[2], en virtud de los cuales la responsabilidad de los perjuicios se genera para todos los codeudores culpables o morosos, de manera muy similar a la solidaridad.

4. Si la obligación es mancomunada, debe permitirse una divisibilidad resolutoria, por lo menos para las situaciones de obligaciones recíprocas divisibles, puesto que el ejercicio de las acciones resolutorias a nadie perjudica. Por lo tanto, el perjuicio resolutorio se calcula separadamente respecto de cada deudor mancomunado.

5. En las obligaciones solidarias, la regla es distinta. Como todos son deudores de lo mismo, el incumplimiento de uno de los deudores acarrea el incumplimiento de los demás. Por lo que, en principio, se debe demandar a todos los deudores de resolución. Sin embargo, para el cálculo de los perjuicios debe aplicarse la regla del artículo 1521 que hace responsable únicamente a los codeudores solidarios culpables o morosos, no a los que no lo hayan sido. A falta de determinación todos deben ser considerados como culpables o morosos.

6. Una hipótesis especial, de un codeudor que no debiera ser condenado por los perjuicios, es la del codeudor solidario no interesado, ya que no puede ser considerado como culpable o moroso. Para estos efectos, el acreedor debiera tener noticia de su calidad, de lo contrario se le aplicará el régimen general de responsabilidad de la codeudoría solidaria.

\section{Referencias}

Abeliuk Manasevich, R. (2014). Las obligaciones. Santiago de Chile: LegalPublishing-Thomson Reuters.

Alessandri Rodríguez, A. (2003). De la compraventa y de la promesa de venta. Santiago de Chile: Editorial Jurídica de Chile.

Baraona González, J. (1997). Responsabilidad contractual y factores de imputación de daños: apuntes para una relectura en clave objetiva, Revista Chilena de Derecho, 24 (1), 151-177.

Barcia Lehmann, R. (2008). Lecciones de Derecho Civil Chileno: De la teoría de las obligaciones. Santiago de Chile: Editorial Jurídica de Chile.

Bustamante Salazar, L. (2005). Autonomía del equivalente pecuniario o su integración dentro de la indemnización de daños y perjuicios. Varas Braun, Juan Andrés y Turner Saelzer, Susan (coords.). Estudios de Derecho Civil. Santiago de Chile: LexisNexis, 363-382.

Caffarena Laporta, J. (1980). La solidaridad de deudores: Excepciones oponibles por el deudor solidario y modos de extinción de la obligación en la solidaridad pasiva. Madrid: Editorial Revista de Derecho Privado.

Clemente Meoro, M. (1998). La facultad de resolver los contratos por incumplimiento Valencia: Tirant lo Blanch.

Contardo González, J. I. (2015). Indemnización y resolución por incumplimiento Santiago de Chile: Thomson Reuters.

Corral Talciani, H. (2010a). La cláusula penal en la resolución del contrato, en Corral Talciani, H (2010). Contratos y daños por incumplimiento. Santiago de Chile: Abeledo Perrot - Legal Publishing, 253-274.

Corral Talciani, Hernán (2010b). La extensión del resarcimiento de los daños contractuales: las reglas de la causalidad y de la previsibilidad, en Corral Talciani, Hernán, Contratos y daños por incumplimiento. Santiago de Chile: Abeledo Perrot - Legal Publishing, 141-204.

Cristóbal Montes, A. (1990). La estructura y los sujetos de la obligación. Madrid: Civitas.

Dell'Aquila, E. (1981). La resolución del contrato bilateral por incumplimiento. Salamanca: Ediciones Universidad de Salamanca.

Delvincourt, C. E. (1825). Cours de Code Civil. Bruxelles: P. J. de Mat.

Díez-Picazo, G. (1996). La mora y la responsabilidad contractual. Madrid: Civitas.

Elorriaga de Bonis, F. (2010). Derecho sucesorio. Santiago de Chile: Abeledo Perrot - Legal Publishing. 
Fernández Gregoraci, B. (2003). Resolución del contrato sobre el bien en comunidad. Legitimación activa de los comuneros, Anuario de Derecho Civil, LVI (4), 1675-1700.

Fueyo Laneri, F. (2004). Cumplimiento e incumplimiento de las obligaciones. Santiago de Chile: Editorial Jurídica de Chile.

García Goyena, F. (1852). Concordancias, motivos y comentarios del Código Civil español. Madrid: Imprenta de la Sociedad Tipográfico-Editorial.

Gatica Pacheco, S. (1959). Aspectos de la indemnización de perjuicios por incumplimiento de contrato. Santiago de Chile: Editorial Jurídica de Chile.

Guzmán Brito, A. (2013). Derecho Privado Romano. Santiago de Chile: Legal Publishing-Thomson Reuters.

López Díaz, P. V. (2015). La autonomía de la indemnización de daños por incumplimiento de un contrato bilateral en el Código Civil Chileno. Santiago de Chile: Thomson Reuters.

Meza Barros, R. (2007). Manual de Derecho Civil. De las obligaciones. Santiago de Chile: Editorial Jurídica de Chile.

Peñailillo Arévalo, D. (2003). Obligaciones. Santiago de Chile: Editorial Jurídica de Chile.

Pescio, V. (1961). La acción resolutoria ejercitada por uno de los herederos del vendedor, Revista de Derecho y Jurisprudencia, 59 (1ª parte), 88-91.

Pizarro Wilson, C. (2010). La responsabilidad contractual en el derecho chileno: función y autonomía, en Pizarro Wilson, Carlos y Vidal Olivares, Álvaro, Incumplimiento contractual, resolución e indemnización de daños. Bogotá: Editorial Universidad del Rosario, 299-311.

Pizarro Wilson, C. (2012). Contra el efecto retroactivo de la resolución por incumplimiento contractual, en Elorriaga de Bonis, Fabián, Estudios de Derecho Civil VII. Santiago de Chile: Abeledo Perrot - Thomson Reuters, 449-460.

Pothier, R. (1839). Tratado de las obligaciones (trad. Sociedad de amigos colaboradores). Barcelona: Imprenta y Litografía de J. Roger.

Rogron, J. A. (1943). Code Civil expliqué. Bruxelles: Societé Berlge du Librarie.

Somarriva Undurraga, M. (1943). Tratado de las Cauciones. Santiago de Chile: Editorial Nascimento.

Vidal Olivares, A. (2007). El incumplimiento de obligaciones con objeto fungible y los remedios del acreedor afectado, en Guzmán Brito, Alejandro (edit.), El Código Civil de Chile (1855-2005). Santiago de Chile: LexisNexis, 495-550.

Vío Vásquez, E. (1945). Las obligaciones condicionales. Concepción: Escuela Tipográfica Saleciana.

\section{JURISPRUDENCIA CITADA}

Ramírez con Ruíz Tagle (1953). Corte Suprema, 14 de enero de 1953 (acción resolutoria), Cita online LegalPublishing: CL/JUR/2/1953.

Zamora con Atalah y otros (2002). Corte Suprema, 3 de septiembre de 2002 (acción de resolución con indemnización de perjuicios), Cita online LegalPublishing: CL/JUR/109/2002.

Fisco de Chile con Descouvieres y otros (2004). Corte Suprema, 7 de octubre de 2004 (acción de cobro de pesos), Cita online LegalPublishing: CL/JUR/2451/2004.

Sociedad Rochet con Rochet S.A y Club Deportivo Unión Española (2006). Corte Suprema, 13 de septiembre de 2006 (acción de indemnización de perjuicios), Cita online LegalPublishing: CL/JUR/2972/2006.

Navarrete con Empresa Metropolitana de Obras Sanitarias (2008). Corte Suprema, 6 de mayo de 2008 (acción ordinaria de cumplimiento de contrato), Cita online LegalPublishing: CL/JUR/6733/2008.

Plaza con Sociedad Agrícola SACOR Ltda. (2008). Corte Suprema, 6 de mayo de 2008 (acción de indemnización de perjuicios), Cita online LegalPublishing: CL/JUR/3556/2008. 